\title{
Congenital stenosis and atresia of the jejunum and ileum
}

\author{
D. J. $\operatorname{deSA}$
}

From the Department of Pathology, Radcliffe Infirmary, Oxford

SYNOPSIS The macroscopic and microscopic findings in 12 cases of stenosis and/or atresia of the jejunum and ileum are presented. There was considerable uniformity within the series with overlapping of cases of atresia, stenosis, and gut infarction. An analysis of associated lesions in cases coming to necropsy suggests that the infants were suffering from shock. In nine out of the 12 cases there was evidence of intrapartum asphyxia and in eight cases evidence of retardation of intrauterine growth. It is argued that, since many of the associated complications of pregnancy are known to be of importance in the aetiology of gut infarction in the neonatal period, they are likely to be of aetiological significance in the development of atresia and stenosis of the gut. A review of perinatal deaths shows that gut ischaemia of varying degrees of severity is a common finding at necropsy, being noted in 19 out of 56 cases studied. It is suggested that stenosis and atresia are sequelae of previous gut ischaemia.

There is controversy regarding the pathogenesis of congenital stenosis and atresia of the small bowel. The traditional explanation favoured by Stowens (1966) and Morison (1970) is that atresia and stenosis are caused by a failure of recanalization of the bowel lumen following a developmental stage of obliterative epithelial proliferation. Alternatively, Louw and Barnard (1955) have led the opposing school who suggest that the development of stenosis and/or atresia is secondary to a vascular insult. What may be interpreted as a refinement of the latter proposition is the view that intestinal stenosis/ atresia may develop as a consequence of intussusception (Parkkulainen, 1958).

This paper presents the findings in cases of congenital stenosis/atresia of the jejunum and ileum occurring in the United Oxford Hospitals during the 10 years $1962-71$. From the changes seen the possible pathogenesis will be suggested.

\section{Material and Methods}

The records of the Department of Pathology at the Radcliffe Infirmary, Oxford, were searched for cases of intestinal obstruction in stillbirths and neonatal infants. Those cases where intestinal obstruction was due to volvulus, herniae, intussusception, paralytic ileus, or meconium ileus were excluded.

Received for publication 3 October 1972.
Sixteen cases of stenosis or atresia were traced but attention was concentrated on the 12 cases where histological material was available. The older slides were reassessed, fresh sections cut where necessary and stained as thought to be most appropriate.

Details of age, sex, birth weight, gestation, obstetrical history, postnatal progress, age at which symptoms presented, and associated malformations were extracted from the clinical notes and, where applicable, the necropsy reports.

In view of the apparent clinical associations further neonatal necropsy material was studied. This included sections of small bowel from 15 cases associated with preeclamptic toxaemia, 12 associated with maternal antepartum haemorrhage, 21 cases with intrapartum asphyxia, and eight cases where congenital cardiac malformations were associated with neonatal death.

\section{Results}

A summary of the main findings in the 12 cases is shown in Table $I$.

MACROSCOPIC FEATURES

Single lesions of the bowel were found in eight of the 12 cases, and multiple lesions were seen in the four remaining cases.

\section{Atresia}

In two cases there was at least one site of complete 1063 


\begin{tabular}{|c|c|c|c|c|c|c|c|c|c|}
\hline $\begin{array}{l}\text { Case } \\
\text { No. }\end{array}$ & Sex & $\begin{array}{l}\text { Gestation } \\
(w k)\end{array}$ & $\begin{array}{l}\text { Birth } \\
\text { Weight } \\
(g)\end{array}$ & $\begin{array}{l}\text { Birth } \\
\text { Weight } \\
\text { Score }\end{array}$ & $\begin{array}{l}\text { Age at } \\
\text { Onset of } \\
\text { Symptoms }\end{array}$ & Types of Lesion & $\begin{array}{l}\text { Pathology of Gut } \\
\text { Lesions }\end{array}$ & $\begin{array}{l}\text { Associated Vascular } \\
\text { Lesions (Necropsy } \\
\text { Cases Only) }\end{array}$ & $\begin{array}{l}\text { Associated Clinical } \\
\text { Findings }\end{array}$ \\
\hline 1 & Male (M) & 38 & 2890 & 0 & 2 days & $\begin{array}{l}\text { Multiple lesions; } \\
\text { atresia with } \\
\text { mesenteric defect } \\
\text { and multiple } \\
\text { stenoses }\end{array}$ & $\begin{array}{l}\text { (1) Fibrous cord } \\
\text { with haemosiderin } \\
\text { macrophages } \\
\text { (2) Granulation } \\
\text { tissue and simple } \\
\text { mucosa }\end{array}$ & $\begin{array}{l}\text { Intraventricular } \\
\text { haemorrhage, } \\
\text { bilateral, } \\
\text { capillary thrombi }\end{array}$ & $\begin{array}{l}\text { Threatened abortion, } \\
\text { old retroplacental } \\
\text { clot noted on } \\
\text { delivery }\end{array}$ \\
\hline 2 & $\mathbf{M}$ & 38 & 3380 & 0 & 3 days & $\begin{array}{l}\text { Solitary } \\
\text { stenotic lesion, } \\
\text { discoloured } \\
\text { serosal surface }\end{array}$ & $\begin{array}{l}\text { Granulation tissue, } \\
\text { haemosiderin } \\
\text { simple mucosa }\end{array}$ & - & $\begin{array}{l}\text { Marked foetal } \\
\text { bradycardia, } \\
\text { meconium in liquor } \\
\text { (intrapartum } \\
\text { asphyxia) }\end{array}$ \\
\hline 3 & Female (F) & 39 & 2910 & 0 & 4 days & $\begin{array}{l}\text { Solitary stenotic } \\
\text { lesion, } \\
\text { discoloured } \\
\text { serosa }\end{array}$ & $\begin{array}{l}\text { Simple flattened } \\
\text { mucosa, numerous } \\
\text { haemosiderin } \\
\text { macrophages }\end{array}$ & - & $\begin{array}{l}\text { Rhesus } \\
\text { isoimmunization }\end{array}$ \\
\hline 4 & $\mathbf{F}$ & 40 & 3360 & 0 & 1 day & $\begin{array}{l}\text { Collapsed } \\
\text { segment preceded } \\
\text { by vascular } \\
\text { constricting } \\
\text { bands proximally }\end{array}$ & $\begin{array}{l}\text { Collapsed segment } \\
\text { normal histologic- } \\
\text { ally; extensive } \\
\text { mucosal ulceration } \\
\text { with regenerating } \\
\text { mucosa proximally }\end{array}$ & - & $\begin{array}{l}\text { Severe foetal } \\
\text { bradycardia } \\
\text { (intrapartum } \\
\text { asphyxia) }\end{array}$ \\
\hline 5 & $\mathbf{F}$ & 32 & 1200 & -1 & 1 day & $\begin{array}{l}\text { Diaphragm } \\
\text { across jejunum } \\
\text { (solitary lesion) }\end{array}$ & $\begin{array}{l}\text { Fibrous tissue in } \\
\text { diaphragm }\end{array}$ & $\begin{array}{l}\text { Capillary thrombi; } \\
\text { bilateral segmental } \\
\text { necrosis of adrenal } \\
\text { glands }\end{array}$ & $\begin{array}{l}\text { Preeclamptic } \\
\text { toxaemia; foetal } \\
\text { bradycardia }\end{array}$ \\
\hline 6 & $\mathbf{F}$ & 36 & 1800 & -1 & 2 days & Multiple stenoses & $\begin{array}{l}\text { Varying pattern; } \\
\text { mostly simple } \\
\text { mucosa and } \\
\text { scarring in stenotic } \\
\text { segments }\end{array}$ & Capillary thrombi & $\begin{array}{l}\text { Antepartum } \\
\text { haemorrhage; foetal } \\
\text { bradycardia }\end{array}$ \\
\hline 7 & $\mathbf{M}$ & 37 & 2300 & -1 & 3 days & $\begin{array}{l}\text { Solitary stenotic } \\
\text { segment near } \\
\text { terminal ileum }\end{array}$ & $\begin{array}{l}\text { Granulation tissue } \\
\text { and marked scar- } \\
\text { ring of muscularis } \\
\text { in stenotic segment }\end{array}$ & $\begin{array}{l}\text { Extensive bilateral } \\
\text { segmental necrosis } \\
\text { in adrenal glands } \\
\text { Capillary thrombi }\end{array}$ & $\begin{array}{l}\text { Preeclamptic } \\
\text { toxaemia; foetal } \\
\text { bradycardia }\end{array}$ \\
\hline 8 & $\mathbf{M}$ & 39 & 2670 & -1 & 1 day & $\begin{array}{l}\text { Solitary stenotic } \\
\text { lesion with } \\
\text { patch of acute } \\
\text { necrosis } \\
\text { proximally }\end{array}$ & $\begin{array}{l}\text { (1) Granulation } \\
\text { tissue and early } \\
\text { scarring in stenotic } \\
\text { segment } \\
\text { (2) Acute full- } \\
\text { thickness necrosis }\end{array}$ & $\begin{array}{l}\text { Bilateral intra- } \\
\text { ventricular } \\
\text { haemorrhages } \\
\text { Capillary thrombi }\end{array}$ & $\begin{array}{l}\text { Severe foetal } \\
\text { bradycardia } \\
\text { (intrapartum } \\
\text { asphyxia) }\end{array}$ \\
\hline 9 & $\mathbf{F}$ & 41 & 2640 & -1 & 1 day & $\begin{array}{l}\text { Solitary stenotic } \\
\text { lesion }\end{array}$ & $\begin{array}{l}\text { Extensive scarring } \\
\text { of muscularis and } \\
\text { simple mucosa; } \\
\text { arterial intimal } \\
\text { plaques }\end{array}$ & None seen & $\begin{array}{l}\text { Foetal bradycardia } \\
\text { (intrapartum } \\
\text { asphyxia) }\end{array}$ \\
\hline 10 & $\mathbf{M}$ & 38 & 2520 & -1 & 3 days & $\begin{array}{l}\text { Solitary stenotic } \\
\text { lesion; } \\
\text { discoloured } \\
\text { serosa }\end{array}$ & $\begin{array}{l}\text { Scarred stenotic } \\
\text { segment, simple } \\
\text { mucosa, numerous } \\
\text { haemosiderin } \\
\text { macrophages, } \\
\text { splitting of } \\
\text { muscularis mucosa }\end{array}$ & 一 & $\begin{array}{l}\text { Foetal bradycardia } \\
\text { (Placenta said to } \\
\text { be extensively } \\
\text { 'infarcted') }\end{array}$ \\
\hline 11 & $\mathbf{F}$ & 43 & 2560 & -1 & 1 day & $\begin{array}{l}\text { Solitary stenotic } \\
\text { segment }\end{array}$ & $\begin{array}{l}\text { Mucosal ulceration } \\
\text { and granulation } \\
\text { tissue replacement; } \\
\text { early scarring }\end{array}$ & None seen & $\begin{array}{l}\text { Transposition of } \\
\text { great vessels; } \\
\text { ventricular septal } \\
\text { defect }\end{array}$ \\
\hline 12 & $\mathbf{M}$ & 39 & 1480 & -2 & 2 days & $\begin{array}{l}\text { Multiple stenotic } \\
\text { segments }\end{array}$ & $\begin{array}{l}\text { Variable pattern } \\
\text { (as in case 6) }\end{array}$ & $\begin{array}{l}\text { Scattered capillary } \\
\text { thrombi }\end{array}$ & $\begin{array}{l}\text { Preeclamptic } \\
\text { toxaemia; foetal } \\
\text { bradycardia }\end{array}$ \\
\hline
\end{tabular}

Table I Summary of main features in cases with atresia and/or stenosis

obliteration of the lumen. The first case (case 1) was associated with a deficiency of the mesentery and the bowel at this point was represented by a fibrous cord. In this case there were other areas of apparent atresia of the small bowel but on histological examination a small lumen could be identified in each of these zones. In the second case the lumen was occluded by a thin diaphragm.
Stenosis

In the remaining 10 cases the bowel appeared $\underset{\omega}{N}$ narrowed but a lumen could be traced. These lesions were classified as 'stenoses'. In one infant (case 4) 0 two congested, band-like vascular constrictions could $\stackrel{\overparen{D}}{\overparen{D}}$ be seen proximal to a collapsed, presumably stenotic, $\stackrel{\mathscr{?}}{+}$ segment of bowel (Fig. 1). On opening the bowel it 7 was apparent that the constrictions corresponded 
to sharply demarcated, circumferential ulcers, and the adjacent mucosa was granular and oedematous (Fig. 2). In three other cases $(2,3,10)$ the stenotic segment and the adjacent bowel wall were noted to be congested and discoloured. In 11 of the 12 cases meconium was noted both proximal and distal to the atretic or stenotic segment of bowel. In one infant (case 8) in addition to an area of stenosis, a zone of complete necrosis of a segment of proximal bowel was present.

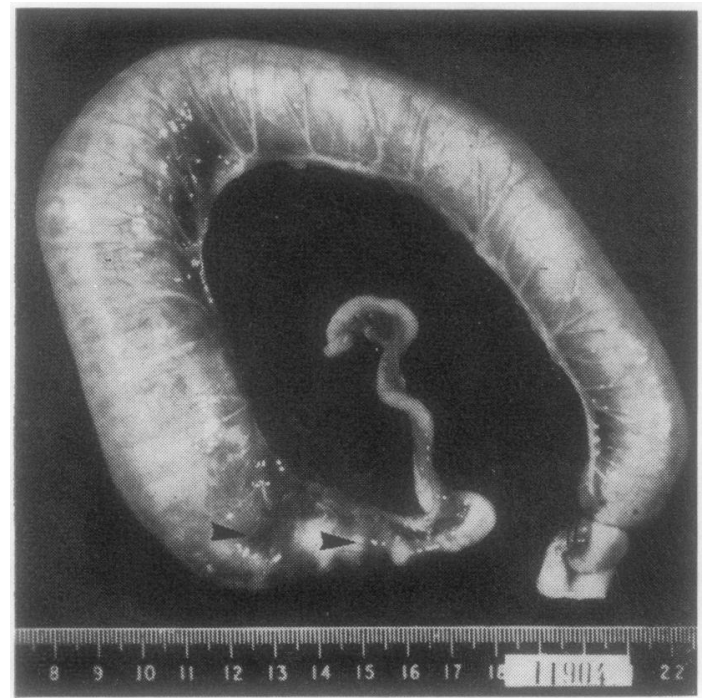

Fig. 1 Loop of bowel showing collapsed bowel distally with congested vascular band-like constrictions proximally (arrowed) (case 4).
MICROSCOPIC FINDINGS

\section{Atretic segments}

The diaphragm noted in case 5 was seen to be made up of loose fibrous tissue with scattered vascular channels, but at necropsy no epithelium was seen. The atretic segment in case 1 was made up of vascular fibrous tissue but abundant haemosiderinladen macrophages were present.

\section{Stenotic segments}

In case 4 (Figs. 1 and 2) the collapsed segment was histologically normal, though the lumen was small. However, as seen in Figs. 1 and 2, areas of ulceration of the mucosa could be seen proximally. The histological features in the ulcerated areas of this case and in the stenosed segments of the other cases were similar with many overlapping features. The changes will be described together as they appeared to belong to a common pattern of lesions related to mucosal destruction and cicatricial repair.

There was extensive ulceration of the mucosa with loss of the lamina propria and its replacement by granulation tissue containing haemosiderin-laden macrophages (Fig. 3). These areas became continuous with others covered by a regenerating flattened cuboidal enithelium spreading over the granulation tissue, producing a mucosal layer devoid of villi and with simple glands (Fig. 4). The muscularis mucosa was scarred and in its most extreme form it was split into two component layers (Fig. 5). Fibrosis of the submucosa spreading into the muscularis propria was seen in all cases but extensive scarring of the muscle coat was a feature in only two
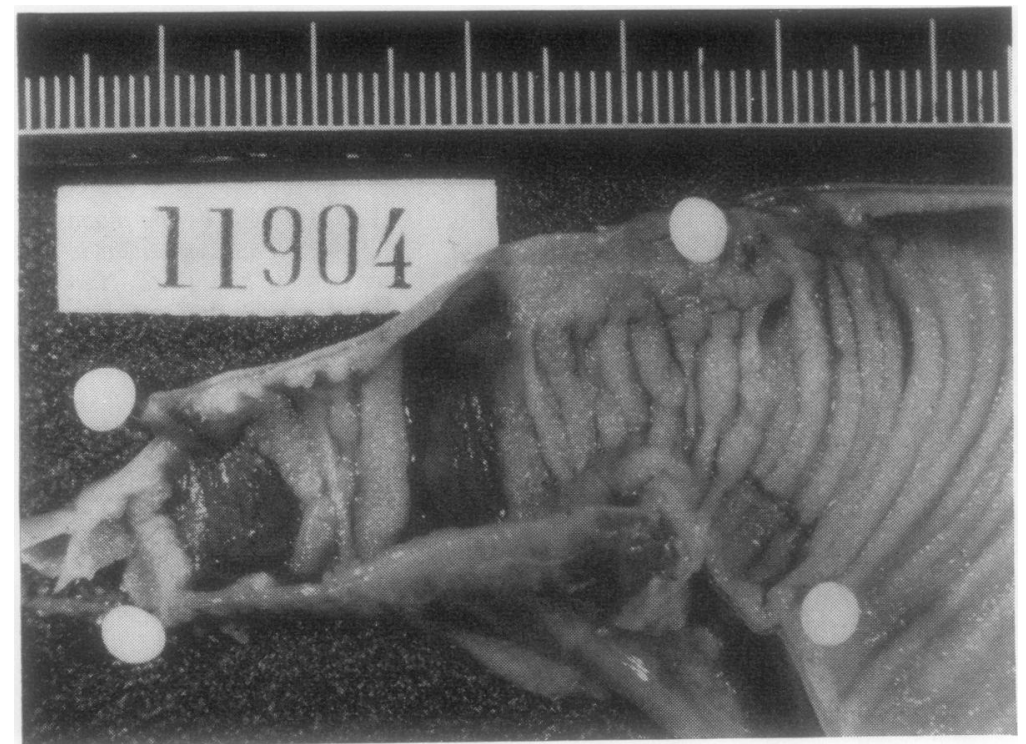

Fig. 2 Same case as in Figure 1. The vascular constricting bands correspond to circumferential ulcers. Note the collapsed segment of bowel distally (on left) and the coarse rough appearance of the mucosa near the ulcers. 


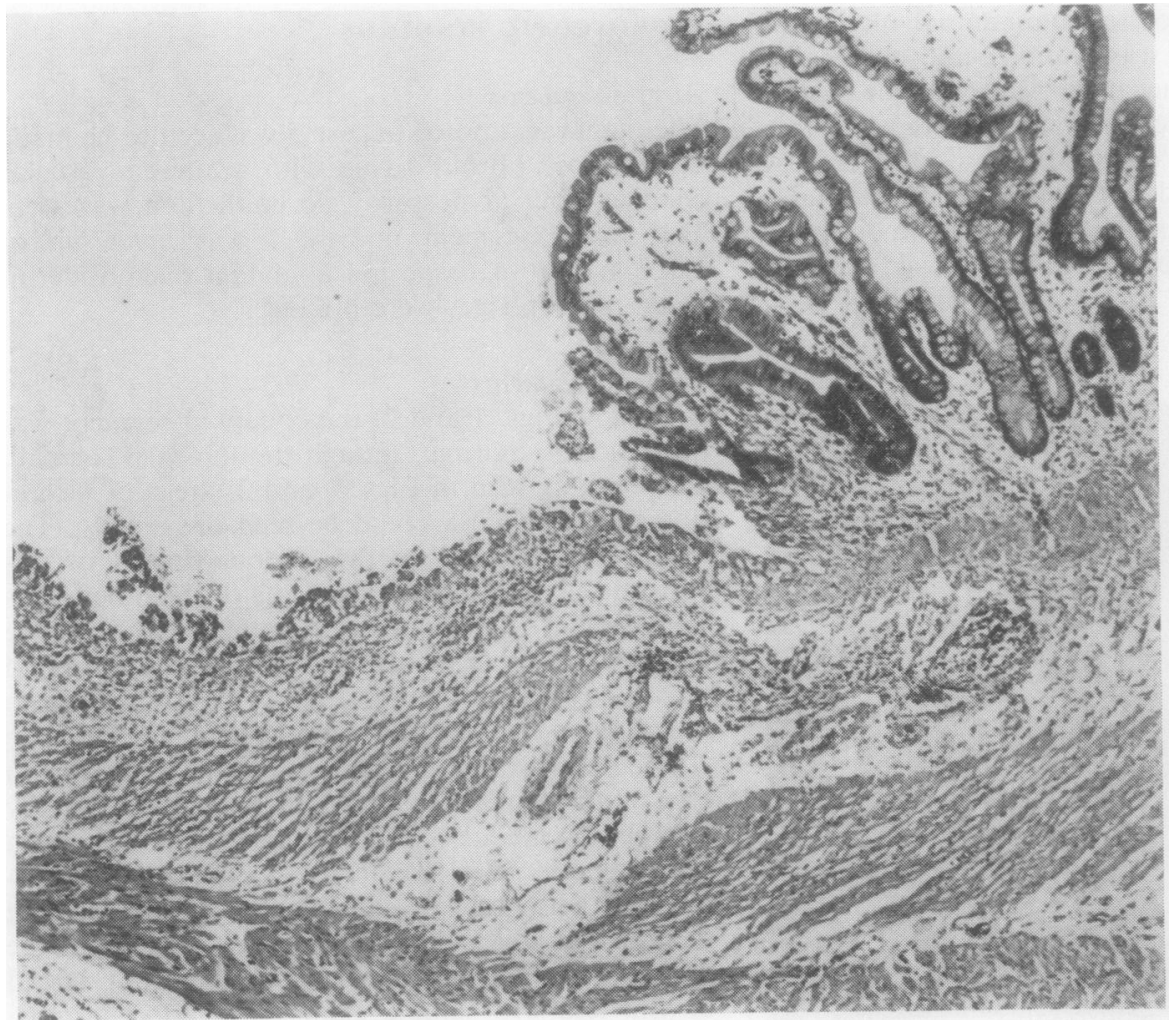

Fig. 3 Case 4: ulcerated area of mucosa corresponding to a vascular constriction. Note the mucosal loss and destruction of the muscularis mucosa and the oedema of the adjacent mucosa (cf Fig. 2).

Haematoxylin and $e$ sin $(H \& E)$

$\times 160$.

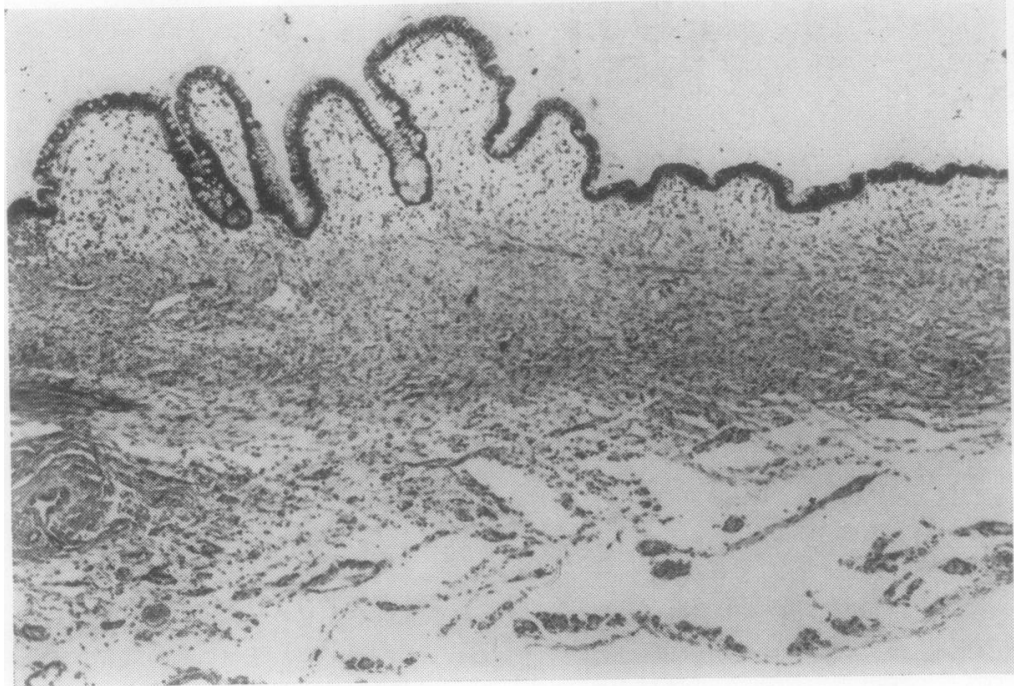

Fig. 4 Case 6: the mucosa in this stenotic segment is extremely simplified. Note the regenerating unilayered epithelium on the right, and the extensive scarring of all layers of the bowel wall. (6) Lendrum's Martius Scarlet Blue $(M S B) \times 128$. 


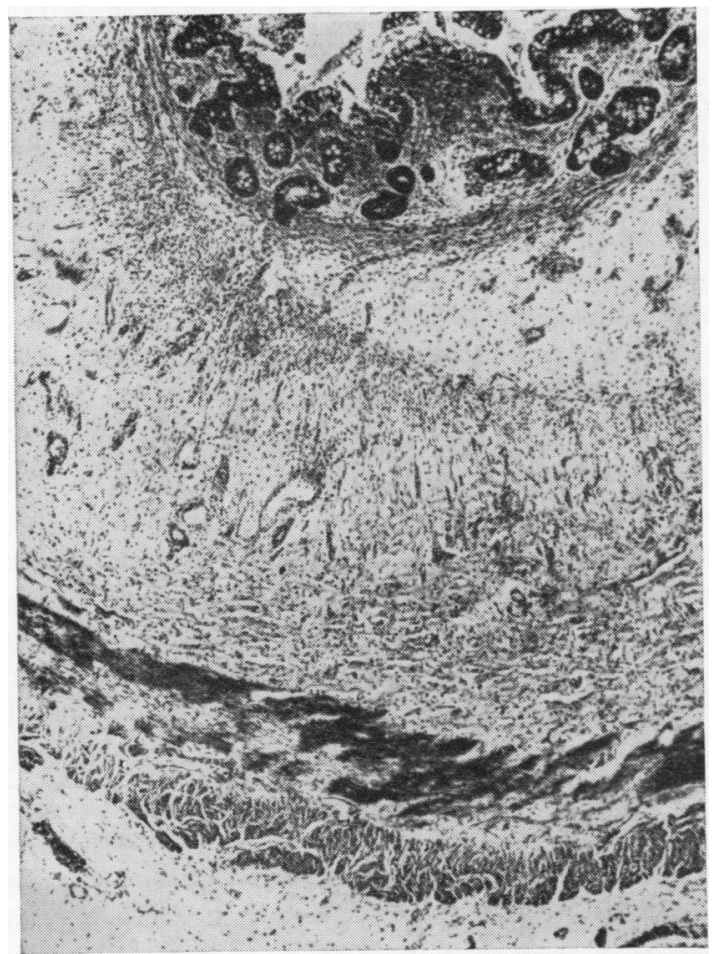

Fig. 5 Case 10: extensive scarring of the muscularis mucosa is seen with splitting of the structure into two component layers. Note the haemorrhage in the lamina propria, and the simple mucosal pattern. Masson's trichrome $\times 120$. cases in this series. In three cases $(6,8,12)$, zones of mucosa devoid of villi were seen in otherwise normal segments of bowel (Fig. 6) suggesting previous minor episodes of mucosal loss.

In four of the specimens removed at laparotomy patchy areas of acute haemorrhage into the lamina propria were seen (Fig. 5). It is possible that this represents the earliest stage in the evolution of the lesions described, though the probability of operative trauma could not be excluded.

In only one infant (case 9) was there any definite structural abnormality of the vessels in the bowel wall. Here there was obvious intimal thickening of several muscular arteries in the submucosa (Fig. 7), suggesting previous thromboembolism.

\section{Lesions of other organs at necropsy}

Eight of the 12 patients died and at necropsy segmental necrosis of the adrenal glands (deSa and Nicholls, 1972) was demonstrable in two cases (5 and $7)$. In a further two cases (1 and 8) bilateral intraventricular haemorrhages were found. In a reassessment of the slides of all eight cases scattered capillary thrombi were demonstrable in six (cases $1,5,6,7,8,12$ ), with the adrenal cortical capillaries, hepatic sinusoids, vasa rectae, and peritubular capillaries of the kidney, being the commonest sites.

\section{ASSOCIATED CLINICAL FACTORS}

\section{Birth weight score}

Only four infants had a birth weight score (Butler and Alberman, 1969) of 0 (within 1 standard devia-

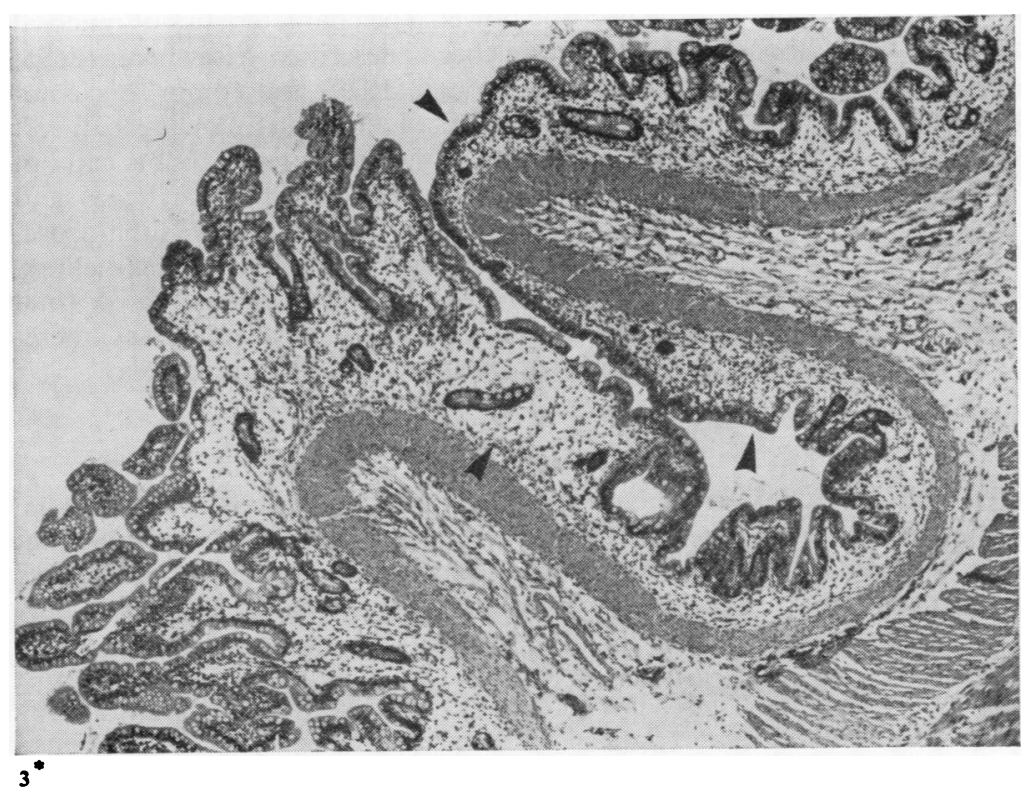

Fig. 6 Case 12: an area of mucosa devoid of villi (arrows) in bowel near zone of stenosis. This may indicate previous mucosal loss. $H \& E \times 120$. 


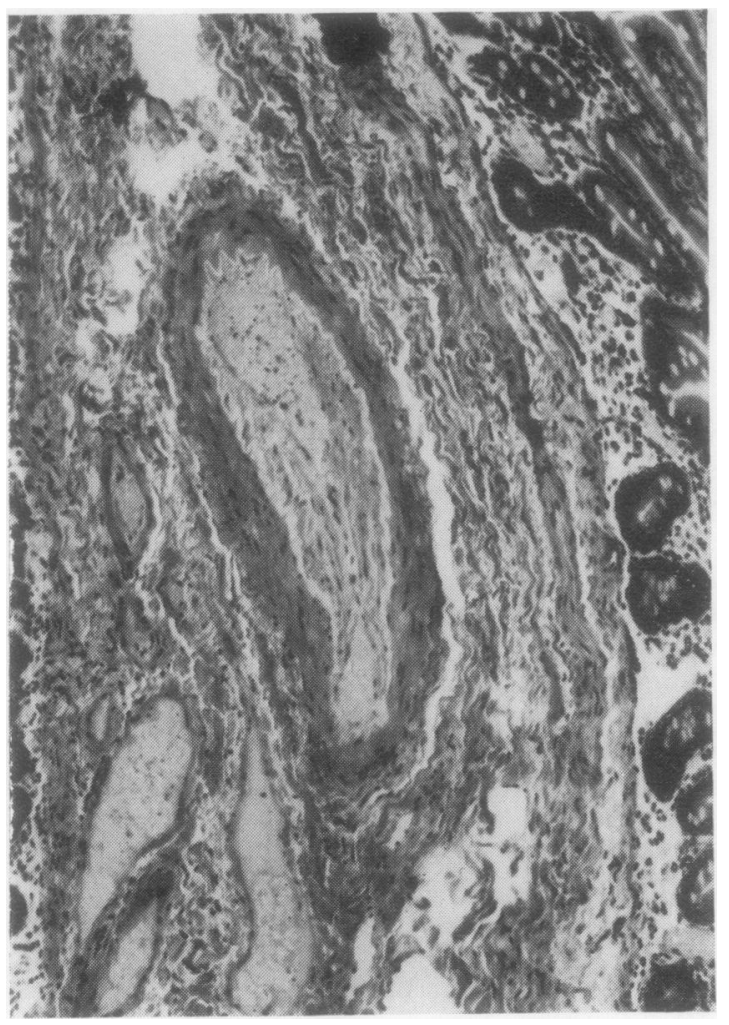

Fig. 7 Case 9: intimal plaques are clearly shown in this muscular artery in the submucosa near a stenotic segment. Picro-Mallory, $\times 600$.

tion of the mean for gestation). Seven had a score of -1 (between 1 and 2 standard deviations below the mean for gestation), and the remaining infant had a birth weight score of -2 (greater than 2 standard deviations below the mean for gestation). Table I suggests a high mortality in infants of a low birth weight for gestation.

\section{Sex distribution}

There were equal numbers of males and females in this series.

\section{Intrapartum asphyxia}

This was considered to be present if there was evidence of sustained foetal bradycardia. (In one case the amniotic fluid was said to be meconiumstained.) Nine of the cases in this series were adjudged to have suffered from intrapartum anoxia. In three infants (cases $5,7,12$ ) this was associated with maternal preeclamptic toxaemia and in a further infant with accidental antepartum haemorrhage (case 6). The cause of the asphyxia in the five remaining cases $(2,4,8,9,10)$ was undetermined or uncertain.

\section{Other associated features}

The clinical history in case 1 was of considerable interest. While the latter months of the pregnancy had been uneventful, examination of the clinical records showed that between 12 weeks' and 16 weeks' gestation there had been several episodes of maternal vaginal bleeding.

There was one infant suffering from rhesus isoimmunization (case 3) and another infant where stenosis of the bowel was associated with transposition of the great vessels and a ventricular septal defect (case 11).

Age at onset of symptoms

No clear pattern emerged (Table I).

Bowel ischaemia in neonatal deaths

This material was studied for evidence of bowel ischaemia and the results are shown in Table II.

\begin{tabular}{lrllll}
\hline & $\begin{array}{l}\text { No. } \\
\text { of } \\
\text { Cases }\end{array}$ & $\begin{array}{l}\text { Full-thickness } \\
\text { Necrosis }\end{array}$ & $\begin{array}{l}\text { Mucosal } \\
\text { Ischaemia }\end{array}$ & Total \\
\hline Preeclamptic toxaemia & 15 & - & 4 & 4 \\
Antepartum haemorrhage & 12 & 1 & 4 & 5 \\
Intrapartum asphyxia & 21 & 2 & 5 & 7 \\
Congenital heart disease & 8 & 1 & 2 & 3 \\
Total & 56 & 4 & 15 & 19 \\
\hline
\end{tabular}

Table II Bowel ischaemia in neonatal deaths

Necrosis of the entire thickness of the bowel was noted in four cases, two of which had a perforation of the necrotic bowel. The characteristics of mucosal ischaemia have been described elsewhere (deSa, Mucklow, and Gough, 1970) and comprise a combination of several if not all of the following features: capillary dilatation and sludging with or without fibrin deposition, interstitial haemorrhage and oedema of the lamina propria and submucosa, necrosis and sloughing of the mucosal epithelium, and destruction of the muscularis mucosa. A total of 15 cases were noted. In 19 of the 56 cases, therefore, there was evidence of bowel ischaemia.

\section{Discussion}

In this small series the overlap between atresia, stenosis, and infarction of the bowel indicates that they are related conditions and that the obstructive lesions are secondary to ischaemia. Ischaemia may be related to embolism, as suggested in the infant with arterial intimal thickening (case 9), but in most cases it is likely to be related to splanchnic shunting in relation to intrapartum asphyxia as suggested 
earlier (deSa et al, 1970). This would place most cases of neonatal and congenital stenosis of the bowel as an end-stage in the spectrum of gut ischaemia affecting this age group. It is of interest that case 5 of deSa et al (1970) developed a stricture of the large bowel following a previous perforation, and that case 7 in the same series showed evidence of regeneration. Further, the mucosal changes seen in the stenotic segments are extremely similar to the persistent mucosal changes in the colon following the ischaemic phenomena associated with Hirschsprung's disease (Berry, 1969).

The aetiological importance of the complications of pregnancy noted in this series is suggested by the study of the morphology of the small bowel in the neonatal deaths not associated with stenosis (Table II), where it can be seen that ischaemic bowel lesions are a frequent finding in babies suffering from intrapartum asphyxia. The case for the importance of intrapartum asphyxia, and in particular the complications noted in this series, in the aetiology of ischaemia of the gastrointestinal tract has been clearly stated by Lloyd (1969).

It would be unrealistic to suppose that the complications of pregnancy listed in this small series of cases were of importance as acute phenomena only. In an examination of placentae from a large number of pregnancies complicated by the same abnormalities, a high proportion were found to have organizing thrombi of varying age in their foetal chorionic veins (deSa, 1971). These venous thrombi were the starting point in the development of intimal cushions in the affected veins and are commonest in infants of low birth weight score, a point noted earlier by other observers (Gruenwald, 1963; Blanc, 1968). The importance of the placental changes is that they indicate longstanding damage occurring within an important part of the foetal circulation. It is regrettable that the placenta was not available for histological examination in any of the cases of the present series. The relatively large number of infants of low birth weight score in the present series, however, is notable, and the apparently high mortality among these infants has been remarked upon.

Table II demonstrates further that ischaemic lesions of the small bowel are not uncommon in congenital heart disease, a situation that finds a parallel in adults with cardiovascular disease and bowel ischaemia (Marston, Pheils, Thomas, and Morson, 1966; McKinnell and Kearney, 1967).

The presence of other ischaemic lesions and scattered fibrin thrombi in infants with stenosis or atresia suggests that the affected infants were suffering from shock (McGovern, 1971), and provides further support for the aetiological role of the complications of pregnancy noted in this series. The presence of scattered ischaemic lesions and fibrin thrombi in other organs would tend to suggest that an incidental intussusception was not of major importance in the cases studied.

If an episode (or episodes) of ischaemia is the basic aetiological factor in the development of stenosis of the bowel it is easy to understand why lanugo, squames, and meconium may be present distal to an atretic segment (Santulli and Blanc, 1961) or why segments of atretic bowel may be separated by relatively normal bowel lined by normal intestinal mucosa and containing meconium (Schultz and Lawrence, 1960). Such findings are incapable of being explained by a failure of recanalization during the organogenesis of the bowel, and it seems appropriate to suggest that this traditional theory should be discarded. In any case, a phase of obliterative epithelial proliferation has never been seen in the small bowel below the duodenum (Johnson, 1910), and it seems inappropriate that it was ever advanced as an explanation of stenosis/atresia of the small or large bowel.

The overlap between frank necrosis and obliterative scarring, the high incidence of complications of pregnancy, and the evidence of necrotic and thrombotic phenomena in other organs all point in the same direction and the uniformity in this small series is striking. There is nothing new in suggesting that ischaemia can produce scarring, and the example of myocardial infarction is familiar to every pathologist. Strictures are an accepted complication of ischaemic colitis in adults (Marston et al, 1966) and it would appear that ischaemic episodes are of primary importance in the development of the homologous complications in the small bowel of the newborn.

I am grateful to the Director of the Gibson Laboratories, Dr A. H. T. Robb-Smith, for permission to study the records.

\section{References}

Berry, C. L. (1969). Persistent changes in the large bowel following the enterocolitis associated with Hirschsprung's disease. $J$. Path., 97, 731-733.

Blanc, W. A. (1968). The future of antepartum morphologic studies. In Diagnosis and Treatment of Fetal Disorders, edited by K. Adamsons (International Symposium), pp. 15-49. Springer, New York.

Butler, N. R. and Alberman, E. D. (1969). Perinatal Problems: The Second Report of the 1958 British Perinatal Mortality Survey, p. 143. Livingstone, Edinburgh.

deSa, D. J. (1971). Intimal cushions in fetal (chorionic) veins in the placenta. Neonatal Society, London, November, 1971.

deSa, D. J., Mucklow, E. S., and Gough, M. H. (1970). Neonatal gut infarction. J. pediat. Surg., 5, 454-459.

deSa, D. J., and Nicholls, S. (1972). Haemorrhagic necrosis of the adrenal gland in perinatal infants: a clinico-pathological study. J. Path., 106, 133-149.

Gruenwald, P. (1963). Chronic fetal distress and placental insufficiency. Biol. Neonat., 5, 215-265.

Johnson, F. P. (1910). The development of the mucous membrane of the oesophagus, stomach and small intestine in the human embryo. Amer. J. Anat., 10, 521-561. 
Lloyd, J. R. (1969). The etiology of gastrointestinal perforations in the newborn. J. pediat. Surg., 4, 77-84.

Louw, J. H., and Barnard, C. N. (1955). Congenital intestinal atresia: observations on its origin. Lancet, 2, 1065-1067.

McGovern, V. J. (1971). Shock. Path. Ann., 6, 279-298.

McKinnell, J. S., and Kearney, M. S. (1967). Haemorrhagic necrosis of the intestine. Brit. med. J., 2, 460-463.

Marston, A., Pheils, M. T., Thomas, M. L., and Morson, B. C. (1966). Ischaemic colitis. Gut, 7, 1-15.

Morison, J. E. (1970). Foetal and Neonatal Pathology, 3rd ed., pp. 341343. Butterworths, London.
Parkkulainen, K. V. (1958). Intrauterine intussusception as a cause of intestinal atresia: a contribution to the etiology of intestinal atresias. Surgery, 44, 1106-1111.

Santulli, T. V., and Blanc, W. A. (1961). Congenital atresia of the intestine: pathogenesis and treatment. Ann. Surg., 154, 939948.

Schultz, L. R., and Lawrence, G. H. (1960). Associated rectal and jejunal atresia in the newborn: report of a case. Pediatrics, 26, $122-125$.

Stowens, D. (1966). Pediatric Pathology, 2nd ed., pp. 569-570. Williams and Wilkins, Baltimore.

\section{Reports and Bulletins prepared by the Association of Clinical Biochemists}

The following reports and bulletins are published by the Association of Clinical Biochemists. They may be obtained from The Administrative Office, Association of Clinical Biochemists, 7 Warwick Court, Holborn, London, WC1R 5DP. The prices include postage, but airmail will be charged extra. Overseas readers should remit by British Postal or Money Order. If this is not possible the equivalent of $50 \mathrm{p}$ is the minimum amount that can be accepted.

SCIENTIFIC REPORTS

3 Automatic Dispensing Pipettes. An assessment of 35 commercial instruments 1967 P. M. G. BROUGHTON, A. H. GOWENLOCK, G. M. WIDDOWSON, and K. A. AHLQUST $80 \mathrm{p}(\$ 2)$

4 An Evaluation of five Commercial Flame Photometers suitable for the Simultaneous Determination of Sodium and Potassium March 1970 P. M. G. BROUGHTON and J. B. DAWSON $80 p(\$ 2)$

\section{SCIENTIFIC REVIEWS}

1 The Assessment of Thyroid Function March 1971 F. V. FLYNN and J. R. HOBBS 60p (\$1.50)

2 Renal Function Tests Suitable for Clinical Practice January 1972 F. L. MTTChELL, N. VEALL, and R. W. E. WATTS 60p $(\$ 1.50)$

\section{TECHNICAL BULLETINS}

9 Determination of Urea by AutoAnalyzer November 1966 RUTH M. HASLAM 40p (\$1)

11 Determination of Serum Albumin by AutoAnalyzer using Bromocresol Green October 1967 B. E. NORTHAM and G. M. WIDDOwsoN 40p (\$1)

13 An Assessment of the Technicon Type II Sampler Unit March 1968 B. C. GRAY and G. K. MCGOWAN 40p (\$1)

14 Atomic Absorption Spectroscopy. An outline of its principles and a guide to the selection of instruments May 1968 J. B. DAWSON and P. M. G. BROUGHTON 40p (\$1)

15 A Guide to Automatic Pipettes (2nd edition) June 1968 P. M. G. BROUGHTON 40p (\$1)
16 A Guide to Automation in Clinical Chemistry May 1969 P. M. G. BROUGHTON 60p (\$1.50)

17 Flame Photometers (2nd edition) 1969 P. WILDING $60 \mathrm{p}(\$ 1.50)$

18 Control Solutions for Clinical Biochemistry (4the N edition) March 1970 P. M. G. BROUGHTON 60p (\$1.50)

19 Spectrophotometers. A comparative list of low-priced instruments readily available in Britain May 1970 C. E. WILDE and P. SEWELL 60p (\$1.50)

20 Quantities and Units in Clinical Biochemistry June 1970 P. M. G. BROUGHTON 60p (\$1.50) More than 30 copies in units of 10 at 20p

21 Filter Fluorimeters: A comparative list of 18 instruments September 1970 H. BRAUNSBERG and s. $s$. BROWN 60p (\$1.50)

22 Bilirubin standards and the Determination of Bilirubin by Manual and Technicon AutoAnalyzer Methods January 1971 BARBARA BILLING, RUTH HASLAM, and N. WALD 60p (\$1.50)

23 Interchangeable Cells for Spectrophotometers and Fluorimeters September 1971 E. S. BROWN and A. H. GOWENLOCK 60p $(\$ 1.50)$

24 Simple Tests to Detect Poisons March 1972 B. W. MEADE et al. $60 \mathrm{p}(\$ 1.50)$

25 Blood Gas Analysers May 1972 K. DIXON 60p (\$1.50)

26 Kits for Enzyme Activity Determination September 1972 S. B. ROSALKI and D. TARLOW 80p (\$2.00)

27 Assessment of Pumps Suitable for Incorporation into Existing Continuous Flow Analytical Systems November 1972 A. FLECK et al 60p (\$1.50) 